\title{
Collaborative professional development and curriculum implementation: insights from program evaluation
}

\begin{abstract}
In its recent Communication, the European Commission calls for greater use of collaborative professional development for teachers in member states (European Commission 2017a). Although peer collaboration is gaining ground, it has not yet become the norm across Europe. Undoubtedly, different kinds of continuing professional development (CPD) are more conducive than others for being collaborative. However, if the intention is to develop teacher collaboration in their routine work, then it makes sense that, where appropriate, the CPD provided should also be collaborative. A form of CPD that is relevant for all countries is the kind offered by external coaches visiting schools to support curriculum reform. This article examines the lessons that can be learned from an evaluation of such a national program of CPD in Ireland. While there were various organizational issues that impeded the nature and extent of teacher collaboration in the CPD, it is argued that the external coach played an important role in creating the conditions for collaborative practices among the teachers later on, including peer coaching. This can then support the cultivation of a culture of 'collaborative professionalism' in schools, as opposed to simply 'professional collaboration' (Hargreaves, O'Connor 2017).
\end{abstract}

Keywords: collaboration, professional development, coaching; curriculum.

\section{Wspólny rozwój zawodowy nauczycieli i wdrażanie programów nauczania: wnioski z oceny rozwoju zawodowego i programów nauczania}

\begin{abstract}
Abstrakt
W ostatnim komunikacie Komisja Europejska apeluje o zwiększenie działań na rzecz „wielowymiarowego", ale uwzględniającego wspólne w państwach członkowskich wymogi w zakresie rozwoju zawodowego nauczycieli (Komisja Europejska 2017a).
\end{abstract}

Mary Immaculate College, Faculty of Education, Director of Continuing Professional Development, CPD, South Circular Road, Limerick, Ireland. 
Chociaż współpraca nauczycieli w tym zakresie zyskuje coraz bardziej na popularności, to jednak nie stała się jeszcze normą w całej Europie. Nadal preferuje się odmienne ścieżki rozwoju zawodowego nauczycieli (CPD) jako bardziej sprzyjające niż osiąganie wspólnych standardów w tym zakresie. Intencją komisji jest zachęcanie do poszerzania współpracy między nauczycielami, by eliminować z ich pracy rutynę. Ma to sens tylko wówczas, kiedy profesjonalny rozwój zawodowy nauczycieli (CPD) opiera się również na wielowymiarowej i dogłębnej współpracy. Formą wspomagania doskonalenia zawodowego nauczycieli, która ma miejsce we wszystkich krajach UE, jest oferta wspierania realizacji programów kształcenia w szkołach przez zewnętrznych doradców czy trenerów. $\mathrm{W}$ artykule poddano analizie wnioski, które zostały wyciągnięte $\mathrm{z}$ ewaluacji krajowego programu doskonalenia zawodowego nauczycieli (CPD) w Irlandii. Pomimo istniejących różnych problemów w organizacji takich form doskonalenia, które utrudniają zakres współpracy nauczycieli, okazało się, że coach odegrał ważną rolę w tworzeniu warunków dla doskonalenia własnej praktyki dzięki kontynuowaniu przez nauczycieli współpracy po wsparciu przez niego w ramach przeprowadzonego coachingu. Troska zatem o kulturę głębokiego, wielowymiarowego, profesjonalnego współdziałania nauczycieli ze sobą z różnych szkół, w przeciwieństwie do „profesjonalnej współpracy" jedynie we własnej placówce, może okazać się bardziej owocną w ich pracy (Hargreaves, O'Connor 2017).

Słowa kluczowe: współpraca, rozwój zawodowy nauczycieli, coaching, program kształcenia.

\section{Introduction}

Studies have emphasized the importance of collaborative professional development as shown in the latest TALIS report (OECD, 2014). In its recent Communication, the European Commission calls for greater use of collaborative professional development in member states, highlighting that high-performing teachers collaborate (European Commission 2017a). However, it also notes that while 'teaching as a team, observation of other teachers, and wider professional learning communities are gaining ground as powerful forms of peer collaboration', these are not yet the norm across Europe (ibidem 2017a: 9). This raises questions regarding the impediments to a greater adoption of such collaboration in teachers' professional development.

It is reasonable to suggest that different kinds of professional development are more conducive than others for collaboration. This variation reflects the range of purposes which CPD may be expected to serve. The OECD (2005) has identified four such purposes (keywords put in bold by this author):

- Activities intended to facilitate the implementation of policy or educational reforms,

- Task-oriented professional development aimed towards preparation of staff for new functions, 
- School-based professional development aimed at serving the aim of school development,

- Personal professional development for professional enrichment and further education (OECD 2005: 124).

A form of CPD that is relevant for all countries and relates in some way to each of the first three purposes cited is the kind offered by external support services, established to support curriculum implementation through visits to schools by coaches/advisers/facilitators. This article examines the lessons that can be learned by drawing on an evaluation of such a national program of professional development in Ireland, selected findings of which have been used elsewhere (Paor de $2015,2016)$. Given that many education systems need to embark upon such CPD provision from time to time, in order to support curriculum reform, the results should be of relevance for contexts across Europe and beyond. While the promotion of collaboration may not be an explicit goal of the professional development established to support such reform, if teachers are to collaborate more in their routine work, then it makes sense that the CPD provided should also be collaborative, at least to some degree. This would mean teachers were more inclined to collaborate later on in their own ongoing implementation efforts. In other words, as an outcome of the professional development, there is a need to have moved further along a journey of greater collaboration in routine work in schools and classrooms.

The article examines therefore the issues that arise and the extent to which such a support service can offer professional development that is collaborative. In doing so, it will highlight certain organizational issues that need to be overcome, but also emphasize the need for the professional development itself to be collaborative, rather than simply employing traditional forms of CPD and then expecting teachers to collaborate later. This is essential for creating the conditions for 'collaborative professionalism' in schools, as opposed to simply 'professional collaboration' (Hargreaves, O'Connor 2017).

\section{Literature review}

The importance of including a collaborative element in teachers' professional development is widely established (Villegas-Reimers 2003). In fact, research has shown for quite some time that CPD should be experiential, grounded in inquiry, collaborative, sustained and derived from teachers' work with their students (Darling-Hammond, McLaughlin 1995). This has not changed and in a more recent contribution, Darling-Hammond reports that the job-embedded forms of professional learning which reflect this 'are taking greater root, often organized around teachers' work with curriculum development through collaborative planning, lesson study and action research of various kinds' (Darling-Hammond 2017: 303). 
Collaboration needs to be interactional, involving sharing of knowledge and focusing on teachers' communities of practice rather than individual teachers. However, it is also necessary to distinguish between various kinds of collaboration as it may involve different kinds of teacher engagement for fulfilling particular purposes. According to a distinction made in the TALIS report, for instance, the term 'cooperation' refers to such activities as information exchange and co-ordination for teaching, while the term 'collaboration' is used where teachers are working and learning together at a deeper level (OECD 2014: 166).

An example of such deeper collaboration is the lesson study, a particular feature of CPD in Japan and China. The most important features of the Japanese 'lesson study' or jugyokenkyu and the Chinese 'teacher research group' or jiaoyanzu include the use of the teacher's classroom as a laboratory for CPD, action research, and balance between teacher initiative and outside assistance (Schwille et al. 2007: 112). Teachers in Japan and China are also accustomed to being observed by, and receiving feedback from peers.

In addition to the kinds of CPD mentioned above (collaborative planning, lesson study and action research and other inquiry), collaboration may also involve the use of observation and coaching. McKenna and Walpole (2008) identify a number of different models of coaching, listed in order of increasing intrusiveness' that are relevant for the current context: mentoring new teachers; peer coaching; cognitive coaching; subject-specific coaching; program-specific coaching; reform-oriented coaching. These practices become increasingly directive and challenging towards the end of the list while mentoring and peer coaching are considered less directive (even non-directive) and encouraging. This variety reflects the fact that coaching may be offered by different professionals for different purposes (namely peers, supervisors, consultants, etc.).

In terms of collaboration, peer coaching may be used to support educational change where, after the instructional strategy has been demonstrated in traditional outside-the-classroom professional development, teachers act as 'coaches' for one another in their own classrooms observing each other teach (McKenna and Walpole 2008: 7). This was the case with the CPD provided to support the curriculum reform discussed later in the article. Elsewhere, the term 'collaborative (co)coaching' is used, defined as 'a structured, sustained process between two or more professional learners to enable them to embed new knowledge and skills from specialist sources in day-to-day practice' (Cordingley et al. 2005). The term 'reciprocal peer coaching' is also used, described as 'usually a short-term relationship which can be used to help embed change, raise performance, raise impact and assist in skill development' (Rhodes et al. 2004: 25). These authors use the term to indicate that teachers take turns being a teacher coach and a coached teacher.

Lesson observation is an essential part of such coaching. However, there are certain challenges as lesson observation can often be 'deemed contrived and/or too teacher-focused being more associated with teacher accountability than with 
learning' (Ó Murchú 2009: 98). Ó Murchú therefore advocates greater use of teamteaching as a way of exploiting the potential of lesson observation. Creating a climate of trust and using observation checklists which are focused on teaching and learning (as opposed to those focused on the teacher) can also ensure the best use of observation. This is relevant for many countries, given the emphasis on school self-evaluation where peer observation, or what is called 'Professional collaborative review' in the Irish context (DES 2016), is being promoted as one of the approaches to enable schools evaluate the quality of teaching and learning. Of course, there is also a kind of peer coaching that may be initiated by schools themselves, and not necessarily as a follow-on to an intervention from an external coach.

However, as a prelude to the kind of peer coaching described above, and to the kind envisaged in the work (Joyce et al. 1988, 1999), teachers share plans and experiences, working closely with the external coach, who uses a workshop approach to introduce new skills and knowledge. This allows teachers to engage in experimentation, observation, reflection, exchange of professional ideas, and shared problem-solving, leading later to the use of peer coaching. These authors, whose research was used in the conceptualization of the support service discussed later, situate their work on coaching in the context of school improvement, which they define as 'the creation of a natural, organic, evolutionary state where continuous efforts to make the school better are routine', and for creating a 'collaborative, collegial, self-renewing culture in schools' (1999: 8).

This relates to the distinction that Hargreaves and 0'Connor (2017) make between 'professional collaboration' and 'collaborative professionalism'. These authors note that 'not all kinds of collaboration are desirable or effective'. and therefore they make the case for collaborative professionalism, as a deeper and more rigorous form of professional collaboration and define it as follows:

Collaborative professionalism is about how teachers and other educators transform teaching and learning together to work with all students to develop fulfilling lives of meaning, purpose, and success. It is organized in an evidenceinformed, but not data-driven way through rigorous planning, deep, and sometimes demanding dialogue, candid but constructive feedback, and continuous collaborative inquiry (ibidem: vi).

They state that the development of collaborative professionalism in teachers' work has been a long one and that five different phases characterized by a dominant issue may be identified in this journey over the last fifty years: (1) emergence; (2) doubt; (3) design; (4) opposition; (5) transformation.

In the first phase, professional collaboration is seen as a welcome alternative to individualism with demonstrated positive impact on student learning. This can be followed by doubts, especially if there is an 'overreliance on talk rather than action', or when collaboration is designed to implement top-down mandates, leading to what has been termed 'contrived collegiality' (ibidem 2017: vii). In the 
third phase, progress is made in using specific models of professional collaboration, for example, professional learning communities and collaborative action research. The fourth phase is dominated by opposition from forces that favor competition, rather than collaboration, depicting the latter as having little or no impact. In the final phase, professional collaboration transitions to deeper forms of collaborative professionalism and is embedded in the culture and life of the school, where educators actively care for and express solidarity with one another as fellowprofessionals (Hargreaves, O'Connor 2017: vii). This represents something deeper and more sustained than professional collaboration.

The question then arises how such collaborative professionalism can be cultivated. This article considers the role played by a CPD program designed to support curriculum reform and examines the extent to which it could support the use of peer coaching within a culture of collective professionalism over the longer term.

\section{The CPD program}

These issues will be examined with reference to an evaluation of the Regional Curriculum Support Service (RCSS) set up in 2001 to support the implementation of a new Primary School Curriculum in Ireland. The CPD initially took the form of training seminars delivered to teachers, but the establishment of the RCSS enabled this support to become more tailored to the requests for support from individual schools (Johnston et al. 2007). Its establishment reflected the fact that schools were at various stages in their own curriculum implementation and were working in different contexts, thereby reflecting one of the key ideas highlighted in the Communication from the European Commission discussed earlier: 'Involving schools and teachers in identifying themes and areas of need can help to improve its quality' (European Commission 2017: 8).

The service now operates as the Professional Development Service for Teachers (PDST) and continues to offer in-school support, though not on the same scale, as part of its provision (PDST 2017). The RCSS support to schools was provided by Cuiditheoirí, an Irish word meaning 'supporters' or 'helpers' hereafter referred to as 'coaches'. These were seconded to the service from their own work as primary school teachers. Schools were invited to request support for any aspect of their own curriculum implementation in accordance with their identified needs. Support available from the coaches included facilitated in-school planning meetings and professional dialogue on specific methodologies in the new curriculum. However, of the types of support available, in-class modeling using modeled lessons, described by Joyce et al. (1988), became a very identifiable part of the service. Modeled lessons were available during once-off visits to the school, repeat visits or as part of Sustained Support (over a number of visits subject to a maximum of ten half-day visits or five full days). At the height of the reform effort, schools 
were allocated a number of closure days per year to facilitate local in-school planning. These were reduced subsequently, which meant that when the coach visited the school, children were also present.

\section{Methodology}

The article draws on a survey of teachers' views working in schools that had requested and received support from the service in the previous six months. A sample of 100 schools was selected using random start/fixed interval systematic sampling from a pool of 1344 schools meeting such criteria. Principals in these schools were contacted by letter to request the participation of those teachers who had received some kind of support from the visiting coach. Replacement schools were used to add to the sample where participation was declined. The teachers in these schools were then contacted and invited to participate in either a postal or online survey. The number of final valid questionnaires received amounted to 436, from teachers located in 86 different schools, comprising 337 paper questionnaires and 99 online questionnaires. This represented a $66 \%$ response rate as a percentage of the original intended sample of 663 teachers (being the total number of teachers recorded as being employed in the 100 schools and having had contact with the visiting coach). All of the teachers surveyed had received at least one visit, some had received repeat visits, while others were availing of the Sustained Support model (involving up to the equivalent of five days). The coach's time within a school might be spent in a small number of classrooms only, while it might involve meeting a greater number of staff, as in facilitation of staff meetings.

Although the original evaluation included a range of data sources, this article draws on the views of teachers as expressed in the survey only. While reliance on self-report entails certain limitations and is not considered first-hand evidence (Ingvarson et al. 2005), it can be useful in capturing general trends that can then be explored more substantially in subsequent research.

\section{Results}

The results considered are both quantitative and qualitative and are drawn from the survey of teachers in supported schools as described above.

\section{Quantitative results}

The following chart shows some results from four separate questionnaire items, presented here together for the sake of illustrating some of the key issues being explored. In the questionnaire itself, the four items included additional elements, 
but these are not relevant for current purposes. It ought to be noted that the number of teachers responding to the four items varies slightly each time, i.e., from 407 to 417 , from a total sample size of 436 .

Children's learning in the longer term (407)

Your own curriculum complementation (417)

Callaborative learning among teachers in your school (414)

Your knowlege of the Primary School Curriculum (416)
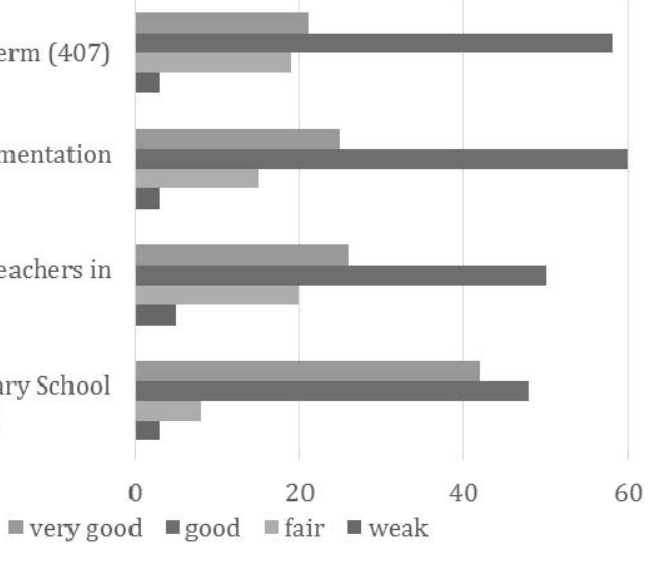

80

Figure 1. Views of teachers with regard to the likely impact of the support service on various outcomes

Source: RCSS survey (2008)

The first item asked teachers to indicate what likely impact they thought the service had on their own curriculum knowledge, including curriculum methodologies, objectives, principles, etc. As illustrated in the gray bars, a total of $42 \%$ of respondents reported that the impact on their knowledge was 'very good', $47 \%$ considered it 'good', while the remaining 17\% considered it either 'fair' or 'weak'.

The second item focused on the perceived impact on the collaborative learning of teachers in the respondents' schools. The results are less positive here, with $26 \%$ judging that the impact was 'very good', approx. 50\% considered it 'good', and the remaining $24 \%$ thought it was 'fair' or 'weak'. If we consider the results for 'very good', it becomes clear that teachers rated the first item more positively, $42 \%$ as against $26 \%$.

Respondents were also less positive about the impact on their own curriculum implementation, with $24 \%$ judging the impact to be 'very good', $59 \%$ considering it 'good', and the remaining $17 \%$ reporting it as 'fair' or 'weak'.

Finally, the views on the impact on children's learning in the longer term are the least positive of all. In this case, $22 \%$ judged the impact to be 'very good', approx. 57\% considered it 'good', while the remaining $21 \%$ thought it 'fair' or 'weak'.

Obviously, the differences between the items are less pronounced if we take the 'very good' and 'good' responses together. Nonetheless, it is clear that while 
teachers are confident about the impact on their knowledge of the curriculum, they are less positive about the extent to which collaborative learning has happened, the extent to which they will put their new knowledge into practice, and the extent to which the children's learning will benefit.

\section{Qualitative responses}

The qualitative responses from teachers (presented in italics below) provide further insight into the reasons for such views. In their comments, teachers referred to the 'enthusiasm, dedication and professionalism' of the coaches who were 'passionate about their work, but yet able to adapt to the needs of this school'. Teachers found modeled lessons particularly useful and reported increased confidence in using methodologies in their own practice that the coach had modeled.

However, organizational issues impacted negatively the teachers' ability to derive best benefits from the visits. Teachers were unable to meet the coach away from their classrooms for professional dialogue unless arrangements were made for their own classes to be supervised. Even where the visit did not include lesson modeling, it was still difficult to arrange meetings in the classroom while the children worked independently. Group meetings with other teachers were hard to organize, though considered highly important. For example, one teacher wrote, 'More benefit for the staff to be met as a group - otherwise no one knows what others have been told - people may be doing different things'. Many of the comments also referred to the need for follow-up visits, for example: 'A follow-up visit would be very effective in ensuring implementation' and could also 'advise on progress made'. Where possible, schools tried to release teachers from their classroom duties and arrange for more than one teacher to meet with the coach at a time. In their responses teachers suggested the need for paid substitution to facilitate this release time so that more teachers could work together with the coach, rather than individually, for instance: 'Together as school staff, not each classroom on their own'. Another teacher noted that: 'it would be more beneficial if all teachers received the same support in school.

However, having noted this preference for collective meetings, the results also show signs that the professional development could be viewed by some as being for the teacher as an individual, rather than on a collective (and therefore collaborative) basis. One teacher expressed her wish to have access to a coach to herself for a week: 'I'd love to have a cuiditheoir to myself for a week with another week for myself and the children'. On the other hand, this can be viewed as simply reflecting the fact that teachers will have individual needs that require one-to-one work with the coach.

The comments also reveal the nature of the engagement during the visit. Many comments suggest teacher co-operation at the level of information exchange. One teacher wrote: 'I personally have found the Visual Arts Cuiditheoir very helpful for 
planning and implementation...and so I've passed on that to the other members of our staff'. However, another teacher referred to the need to 'discuss school plans as a whole-school project and not just as a person with a post of responsibility'. This suggests a collaborative engagement at a deeper collaborative level, rather than simply exchanging plans with the person responsible for the collation of the school plan, i.e., the teacher with a 'post of responsibility'. There were also references to how collaboration could help in ensuring change occurred across the school, not just in isolated classrooms, and creating greater synergy between teacher and school development. One principal emphasized this by writing 'It would be helpful if the Cuiditheoir could see if we are developing... as a whole school, examining continuity and gradual progression at each class level'.

\section{Discussion}

The results highlight the organizational difficulties as a significant impediment for deriving optimum benefit from the service, but also show that teachers saw the value in being able to work as a group. Teachers viewed the impact on their curriculum knowledge more positively than the impact on their collaborative learning, their use of the new curriculum methodologies, and the impact on children's learning ultimately.

At a practical level therefore, the results raise issues regarding the organization of school time - also the subject of a recent report from Eurydice (European Commission 2017b), which provides a range of practices being used in other countries that could be considered. For example in Norway, teachers work a minimum of six days more than the child' school year, for planning, evaluation, competence development, and cooperation with colleagues.

Yet, despite the reported difficulties, the results show that schools were able to improvise and could ensure that in many instances the visit of the coach brought small groups of teachers together to engage in professional dialogue, as part of a modeling and coaching session. However, while this was an important achievement for the demonstration of new methodologies in a classroom environment with children present, the results suggest that something even more important was happening, which relates to the research question being considered in the article, i.e., how a culture of 'collaborative professionalism' can be cultivated in schools (Hargreaves, O'Connor 2017). This more fundamental event was the use of the classroom as a site for professional development, where another teacher, working as a visiting external coach, but still a teacher by profession, engaged with fellow-professionals regarding the curriculum using dialogue, modeling, problemsolving, etc. Therefore, rather than simply modeling a particular methodology, we can say that something more significant was being modeled - the willingness to teach while other fellow professionals observed and participated in professional 
dialogue together. This carried a certain risk for the coach in front of his/her professional peers, but was a powerful statement regarding a willingness to grow professionally.

It is important to note this breakthrough as part of the important groundwork needed for developing a culture of collaboration in schools. Such progress may not be readily demonstrable as a tangible outcome of the kind often needed to justify investment in professional development as illustrated in the value-for-money research. Studies such as the one conducted by the DES on various CPD provision, including the program being discussed here (DES 2007), are likely to become even more important as education systems are increasingly required to show how more is being done with less, and how cost-efficiency is being increased. The results suggest, though, that an efficiency of another kind may be achieved in the longer run with regard to the culture of schooling.

To further develop this point, it is important to acknowledge that, traditionally, teaching has taken place behind the closed doors of the classroom, with teachers' work characterized by isolated 'privatism' given the cellular organization within schools (Lortie 1975). Thus, the work of the coach can play an important role therefore in preparing the ground for greater collaboration within the school in the future. The value in having more than one teacher work with the coach at the same time provides a platform for professional dialogue and for moving later on from the situation where the external coach is teaching to where it is one of the teachers themselves who is teaching as part of peer coaching. It is an important step on the journey towards greater collaboration, for example in the use of lesson study as reported earlier, and in moving from the reform-oriented coaching to peer coaching (McKenna, Walpole 2008). Such collaborative practices are essential components for creating lasting impact in education change (Earley, Porritt 2010).

An important aspect of the work of the coach in the current study was therefore building professional relationships and establishing trust. While this kind of trust requires time, such a gradual approach to educational change also makes sense in the context of Guskey's model of teacher change (2002). This suggests that changes in the beliefs of teachers are likely to take place where they can 'field-test' change proposals in classrooms for themselves and where they can experience first-hand change in learning outcomes (ibidem 2002: 382).

At the same time, the external coach must avoid the situation in which coaching and modeling would simply be seen as a kind of performance or novel diversion, disconnected from their own professional development needs and priorities. This reflects the caution made by Cordingley et al. (2003) who conclude that what is needed is structured collaboration as opposed to 'simply naive discovery or curriculum tourism' with little follow-on in the practice of the teachers, once back in their own classrooms (ibidem et al. 2003: 8). It requires specialist, expert input in relation to the aspect of pedagogy being explored, so that new approaches can be adapted, experimented with and integrated into practice over time. 
Another danger, as mentioned earlier, is an unhelpful association in the minds of teachers between observation and evaluation, especially given the promotion of 'professional collaborative review' of teaching and learning in the context of school self-evaluation. This involves observation and professional dialogue and is defined as 'a practical and powerful method of obtaining direct, first-hand information or evidence about teaching and learning in classrooms and in other learning settings' (DES 2016: 37). It can of course be viewed as a kind of lesson study and the guidelines do indeed go on to emphasize the need for it to be conducted in a collegial and careful way.

To succeed as a method of gathering information during school self-evaluation, professional collaborative review of teaching and learning needs to be conducted in a collegial, respectful way within the terms of an agreed school protocol, using specific, planned criteria (DES 2016: 37).

The danger remains nonetheless, that collaboration is seen as serving the purposes of review and evaluation, rather than teacher learning, especially given the linking of words such as 'evidence' and 'evaluation' with 'collaboration'. It could also be seen as a kind of 'contrived collegiality' (Hargreaves, O'Connor 2017) discussed earlier, thereby hindering progress in moving from 'professional collaboration' to 'collaborative professionalism'.

\section{Conclusion}

The article has considered how a national program of school-based CPD might contribute to a greater use of collaboration in professional development, and ultimately to the way teachers go about their work as collegial professional learners.

The organizational difficulties encountered meant that it was not always possible for the external coach to work in a way that would be most conducive to collaboration among teachers. However, the teachers referred to the benefits that this would mean. They also showed great appreciation for the professionalism of the coaches, who were themselves teachers on secondment from their schools, but first and foremost, teachers just like themselves. Thus, while organizational issues impeded the nature and extent of teacher collaboration in the CPD, the article has made the case that the work of the external coach can help in promoting openness to learning and therefore working collaboratively. It is reasonable to suggest that because teachers had experienced the coach's visit in positive terms, despite the organizational difficulties, it is more likely that they will go on to try collaborate later on. In that regard, the following comment from one of the teachers in the survey is noteworthy 'Best Cuiditheoirí would be fellow staff in school who are familiar with the school situation. If time would be given for staff to work together on a regular basis, it would be more beneficial than having outside help'. 
Returning to the typology developed by McKenna and Walpole (2008), the analysis has provided some signposts for how there could be movement from the reform-oriented coaching at one end of the spectrum to the use of peer coaching at the other. This would also enable progression from 'co-operation' to 'collaboration' as defined in the TALIS study (OECD 2014), i.e., from a low level of collaboration to something deeper and lead ultimately to the cultivation of 'collaborative professionalism' in schools, as opposed to simply 'professional collaboration'.

\section{References}

Casey K. (2006) Literacy coaching: the essentials, Portsmouth, New Hampshire, Heinemann.

Darling-Hammond L. (2017) Teacher Education around the World: What Can We Learn from International Practice?, "European Journal of Teacher Education", 40 (3): 291-309.

Darling-Hammond L., McLaughlin M. W. (1995) Policies that support professional development in an era of reform, "Phi Delta Kappan", 76 (8): 597-604.

de Paor C. (2015) The use of demonstration lessons to support curriculum implementation: invitation or intrusion?, "Professional Development in Education”, 41 (1): 96-108.

Guskey T. (2002) Does it make a difference? Evaluating professional development, "Educational Leadership", 59 (6): 9-27.

Ingvarson L., Meiers M., Beavis A. (2005) Factors affecting the impact of professional development programs on teachers' knowledge, practice, student outcomes and efficacy, "Education Policy Analysis Archives", 13 (10): 1-28.

Johnston K., Murchan D., Loxley A., Fitzgerald H., Quinn M. (2007) The role and impact of the Regional Curriculum Support Service in Irish primary education, "Irish Educational Studies", 26 (3): 219-238.

Joyce B., Showers B. (1988) Student Achievement Through Staff Development, Longman New York.

Joyce B., Calhoun E., Hopkins D. (1999) The new structure of school improvement, Open University Press, Buckingham.

Lortie D. (1975) Schoolteacher, University of Chicago Press, Chicago.

McKenna M. C., Walpole S. (2008) The literacy coaching challenge: Models and methods for grades $K-8$, Guilford, New York. 
OECD (2005) Teachers Matter Attracting, developing and retaining effective teachers, OECD, Paris.

OECD (2014) TALIS 2013 Results: An International Perspective on Teaching and Learning, OECD Publishing, Paris, http://dx.doi.org/10.1787/9789264196261-en

Ó Murchú F. (2009) Team teaching: supporting student and teacher learning in postprimary classrooms, “Learn”, 31: 88-106.

Rhodes C., Beneicke S. (2002) Coaching, Mentoring and Peer-networking: challenges for the management of teacher professional development in schools, "Journal of Inservice Education", 28 (2) : 297-309.

Schwille J., Dembélé, M., Schubert J. (2007) Global perspectives on teacher learning: improving policy and practice, Paris, UNESCO.

Villegas-Reimers V. (2003) Teacher Professional Development: an international review of the literature, Paris, UNESCO.

Zwart R., Wubbels T., Bergen T., Bolhuis S. (2007) Experienced teacher learning within the context of reciprocal peer coaching, "Teachers and Teaching: theory and practice", 13 (2): 165-187.

\section{Electronic sources:}

Cordingley P., Bell. M., Rundell B., Evans D. (2003) The impact of collaborative CPD on classroom teaching and learning. London, EPPI-Centre, Social Science Research Unit, Institute of Education, http://eppi.ioe.ac.uk/cms/LinkClick.aspx?fileticket=zKuM1BP ck20\%3D\&tabid=135\&mid=761 [22.02.2018].

Cordingley P., Bell M., Thomason S., Firth A. (2005) The impact of collaborative CPD on classroom teaching and learning. Review, How do collaborative and sustained CPD and sustained but not collaborative CPD affect teaching and learning?, London, EPPICentre, Social Science Research Unit, Institute of Education, University of London, http://eppi.ioe.ac.uk/cms/Default.aspx?tabid=136 [22.02.2018].

DES (2016) School Self-evaluation Guidelines 2016-2020, Primary, Dublin, Department of Education and Skills,

https://www.education.ie/en/Publications/Inspection-Reports-Publications/EvaluationReports-Guidelines/School-Self-Evaluation-Guidelines- 2016-2020 - Primary.pdf [22.02.2018].

DES (2007) A Value for Money Assessment of Programs managed by the Teacher Education Section, Dublin, Department of Education \& Science, https://www. education.ie/en/Publications/Value-For-Money-Reviews/vfm_review_tes_programs. pdf [22.02.2018]. 
Earley P., Porritt V. (2010) Effective Practices in Continuing Professional Development, London, Institute of Education, University of London.

European Commission (2017a) School development and excellent teaching for a great start in life, Communication from the Commission to the European Parliament, the Council, the European Economic and Social Committee and the Committee of the Regions, http://eur-lex.europa.eu/legal-content/EN/TXT/PDF/?uri=CELEX:52017DC 0248\&from=EN [22.02.2018].

European Commission/EACEA/Eurydice (2017b) The Organisation of School Time in Europe.Primary and General Secondary Education - 2017/18, Eurydice Facts and Figures, Luxembourg, Publications Office of the European Union, https://www. education.ie/en/The-Education-System/International/Eurydice/the-organisation-ofschool-time-in-europe-2017-18.pdf [22.02.2018].

Hargreaves A., O'Connor M. (2017) Collaborative Professionalism, https://www.wiseqatar.org/sites/default/files/rr.12.2017_boston.pdf [22.02.2018].

PDST (2017) Aim and mission statement, Professional Development Service for Teachers (PDST), http://www.pdst.ie/about_us [22.02.2018].

Paor de C. (2016) The impact of school-based continuing professional development: views of teachers and support professionals, "Journal of Irish Educational Studies", vol. 35, no. 3: 289-306, http://www-tandfonline-com.libraryproxy.mic.ul.ie/doi/full/ 10.1080/03323315.2016.1192482 [22.02.2018]. 